\title{
FACEBOOK AS A TOOL FOR DISCURSIVE RESISTANCE: A CASE STUDY
}

\author{
Ehsan Dehghan and Afida Mohd Ali* \\ Faculty of Modern Languages and Communication \\ Universiti Putra Malaysia
}

\begin{abstract}
Iran is one of the few countries in the world with laws of compulsory hijab for women, regardless of their religion. In the last couple of years, Iranian women have formed online communities to resist such laws and voice their dissent. The role of online social networks in causing social change, and the extent to which these New Media can help the processes of emancipation and democratization has been a matter of increasing academic attention. However, there are not enough studies, particularly from a linguistics viewpoint, on the online resistance movement of Iranian women against compulsory hijab. This leaves a gap in our understanding of both the dynamics and strategies of such movements, and also the bigger question of whether or not New Media can be useful tools in advancing human rights, democracy, and equality. This study, employing the Discourse-Historical Approach to Critical Discourse Analysis, investigates a corpora of over 500 Facebook posts by the most popular pages created for the purpose of resisting compulsory hijab in Iran. In contrast to the dichotomization and Xenophobia reported in studies on similar discourses, our findings point to a trichotomized discourse, in which the Self is identified against a negatively represented domestic Other (Oikophobia), and a positively framed foreign Other (Xenophilia). The paper concludes that the use of New Media in this case has led to an illusion of resistance, and how the movement under study is self-destructive, reproducing the same ideologies it is resisting.
\end{abstract}

Keywords: NEW MEDIA, FACEBOOK, RESISTANCE, CRITICAL DISCOURSE ANALYSIS, IRAN, SOCIAL MOVEMENTS

\section{Formation of context}

Iran is one of the few countries in the world with laws enforcing compulsory hijab for all women, regardless of their religion. After the 1979 revolution, the Khomeini-led Shi'a clergy, who gained political power after the expulsion of the pro-West, secular Shah, imposed several laws regarding women's covering in public. Since the beginning days of the new political system, the Islamic practice of hijab became compulsory for all women, and hijab entered the Iranian legal system (Afary \& Anderson, 2005; Justice for Iran, 2014). According to the laws, a breach of standards of hijab is punishable by a fine, imprisonment, whipping, and/or exile. Special sections of the armed forces have been assigned to ensure the implementation of the law, with patrol units having a noticeable presence in major cities. Currently, the section of the police force responsible for the enforcement of the compulsory hijab is often known as the Morality Police.

Although the severity of enforcing such laws has undergone changes under different presidents, the Morality Police has always had a noticeable presence in Iranian cities. At the time of Mahmoud

*Corresponding Author 


\section{FACEBOOK AS A TOOL FOR DISCURSIVE RESISTANCE: A CASE STUDY}

Ahmadinejad, the ex-president of Iran famous for his fundamentalist and revolutionary discourse, the Morality Police had a constant presence in main squares of Tehran, such as Vanak Square. Hassan Rouhani, the current president, made promises to rein the Morality Police in during his presidential elections campaign (Hasan Miri, 2013; Tabnak.ir, 2013). However, after two years of his presidency, the Morality Police is still present in all major cities, though with less patrol units than before (BBC Persian, 2014).

For the last three decades, the heavily state-controlled media have left Iranian women with no tribunal to voice their opinions regarding compulsory hijab. However, in recent years, due to the higher accessibility and popularity of social networking websites, such as Facebook, some Iranian women have formed a movement against compulsory hijab in Iran (Karimi, 2015; Saul, 2015; Threadgould, 2015). Although social networks such as Facebook and Twitter are filtered in the country, citizens often bypass the censorship barriers with different means. A number of Facebook pages have been created by the dissident Iranian women, in which they post their narratives, photos without hijab, opinions, and in general, their dissent. One of these pages, "My Stealthy Freedoms", has gained widespread international attention. With over 800,000 'likes', this Facebook page has enabled Iranian women to find a space to be heard by the world.

The general perception of the resistance movement of these Iranian women has been positive and optimistic, praising them with words such as brave, rebellious, courageous, etcetera (Saul, 2015; Threadgould, 2015). However, a great deal of this optimism has come from western journalistic accounts, without considering the contextual peculiarities of the Iranian setting. An understanding of the context of such movements is necessary before one can pass optimistic judgments. Two major aspects of this context are more significant in this regard: the political system in Iran, and the concept of hijab, as the central point of debate and disagreement between the Iranian government and the dissident Iranian women.

\section{The Iranian political system}

The new government system in Iran after the 1979 revolution is named the Islamic Republic of Iran. Being a republic democracy and an Islamic theocracy at the same time would lead to inevitable contradictions between the two (Afary \& Anderson, 2005). In order to ensure the precedence of Islamic values over democratic norms, a peculiar hierarchy of institutions is in existence in this political system. An understanding of this system is of utmost contextual importance in any attempt to conceptualize the resistance movement, its implications, and in evaluating whether one can be optimistic about it.

The political system of Iran is composed of both democratic and non-democratic institutions. The three main branches of governance in Iran are the Judicial, Executive, and Legislative branches. The president of Iran, who is responsible for the Executive Branch, is chosen by people through public elections every four years. The members of the Legislative Branch also find their way into the parliament through quadrennial public elections. The Judicial Branch is responsible for administration of laws, and its head, the Chief of Justice, is directly appointed by the Supreme Leader, currently being Ayatullah Khamenei. Therefore, this branch of the government is a non-democratic one. 


\section{FACEBOOK AS A TOOL FOR DISCURSIVE RESISTANCE: A CASE STUDY}

Although two of the three main branches of the Iranian political system seem to be democratic, the complexity of this system reveals itself in the higher levels of the hierarchy. Two councils are located above the Legislative Branch: the Guardian Council, and the Expediency Council. The Guardian Council is responsible for approving the candidates of presidential and parliamentary elections, and also observing the compatibility of any laws passed by the parliament with the constitution of Iran and Islamic (Shi'a) laws. The members of the Guardian Council are appointed by the Supreme Leader and the Chief of Justice, who himself is appointed by the Supreme Leader. Therefore, although, the Legislative and Executive branches of the government appear to be democratic institutions, their members need to pass filters directly set by the non-democratic institutions of the government. This leads to a controlled and illusionary democratic process, in which people are free to elect their candidates, but only from a list of candidates pre-approved by the Supreme Leader. Finally, if there is an unresolved issue between the parliament and the Guardian Council, the Expediency Council will have a ruling. Interestingly, all members of this council are appointed by the Supreme Leader. Above all, the Supreme Leader has the capacity to bypass all the councils, and even the constitution of the country, to make rulings.

In brief, the complex web of councils over councils in this political system ensures that any law passed, any president elected, and any decision made in Iran is in line with the ideological perspective of the Supreme Leader. The illusionary nature of democratic processes in the country has important implications for understanding the resistance movement under investigation. We will go into the details of this later on.

\section{Hijab in Islam}

Contrary to common misconceptions, the practice of hijab is required for both men and women within the discourse of Islam (Al-Balagh, 2015; Mutahhari, 2015b). Although the limits of this practice are debated among different Islamic scholars, there is a consensus on covering certain body parts. Regarding men's hijab, the consensus is on covering of the genitals. However, some scholars require their male followers to cover the mid-section of the body, from the navel to the knees. For women, all Islamic scholars agree on covering the hair and the body, except for the face, hands (wrists to fingers), and feet (ankles to toes). Some, however, require women to cover these parts, as well (Mutahhari, 2015b).

The rationale for covering certain body parts among Muslims stems from a number of Islamic notions, namely: the concepts of awra/aurat, zeena/zeenat, and tabarruj. The Arabic term awra/aurat, which is used in the holy book of Muslims, the Quran (24:30-31), refers to 'something which is prone to defect and needs to be protected'. When used as a reference to body parts, it means the body parts which must be covered from people a woman can marry. As for genitals, they must be covered from everyone except for one's spouse. However, the inclusion of certain body parts in this concept is dependent on the jurisprudence of Islamic scholars, who base their ruling on the Quran, the traditions of the prophet, and also the sayings of the prophet (Mutahhari, 2008, 2015a). It is due to this interpretation process that different Islamic scholars suggest different body parts to be covered by Muslim men and women. 


\section{FACEBOOK AS A TOOL FOR DISCURSIVE RESISTANCE: A CASE STUDY}

The other two concepts (zeena/zeenat and tabarruj) more specifically address Muslim women. The concept of zeena/zeenat (the Quran 24:31) can roughly be translated to adornments or beauty, and tabarruj (the Quran 24:60 and 33:33) is showing off or display of one's adornment and beauty. Again, although there is some debate among Islamic scholars on what includes a woman's adornment, the general consensus is on anything which can be worn over a woman's body, such as makeup, jewelry, ornaments, etc. Muslim women are advised to cover these from men they can marry (Al-Balagh, 2015).

In general, these Islamic concepts all fall into the religious concepts of modesty and piety. The rule of thumb in Islam is refraining from acts and behavior which could lead to sexual temptation and incest, which is considered a cardinal sin. Sexual relations are allowed only between married couples in Islam, and the practice of hijab is believed to protect women and men from being tempted into extra-marital sexual affairs and harassment (Mutahhari, 2015b).

Having noted these, the concept of hijab is seen not as a limiting act within the Islamic paradigm. In contrast, it is believed that hijab allows Muslim women to enter social domains, and enjoy a higher level of social activity, free from the danger of being harassed or becoming an object of sexual desire (Al-Balagh, 2015; Mutahhari, 2008), something which is usually referred to as the 'male gaze' in contemporary feminist theorizations (Berger, 1972; Sutton, 2007). In the Iranian context, such a phenomenon was witnessed. Conformity to the rules of Islamic hijab allowed women to pursue education, enter the labour market, and enjoy more social freedom in a traditional and conservative society (Afary \& Anderson, 2005)

\section{Hijab from the western perspectives}

The first encounters of the western world with the Islamic practice of hijab started with the colonization era (El Guindi, 1999; Hoodfar, 1993). The western colonizers, coming from a completely different contextual background, interpreted this symbolic practice from their own point of view (Macdonald, 2006; Mahmood, 2005; Wassef, 2001) . Macdonald (2006) argues that the covering of the women, combined with the harems of the kings of the time, had with it a certain kind of sexual secrecy and fascination for the colonizers. These (mostly) men, coming from a context stranger to such practices, had no other way but to interpret it as a sexualisation and slavery of women (ibid.); a practice which covered women up and kept them in harems, to be sexually exploited exclusively by their husbands.

Such a view proved to become a lasting interpretation of hijab in the western world, both within academia and among the general public (Bilge, 2010). Bilge (2010) refers to it as "the submission frame of thought", in which hijab is seen as a patriarchal, oppressive practice, and women as victims of such values. The western media is shown to be brimming with this negative representation of hijab in Islamic countries, sometimes even representing it with metaphors of 'death mask', 'shroud', etc. (Macdonald, 2006).

With the increase in international immigration waves, many Muslims moved to western countries. Given the significance of hijab in Islam, these Muslims continued its practice in their new setting. This pointed to the deficiency of the "submission frame", since the oppression theorized in the previous settings did not exist in the West. The expectation was that, once in a liberal free country, Muslim 


\section{FACEBOOK AS A TOOL FOR DISCURSIVE RESISTANCE: A CASE STUDY}

women would put aside their hijab (El Guindi, 1999; Shirazi \& Mishra, 2010). However, this did not happen. Once again, the western thought ignored the symbolic and contextual background of the practice, and interpreted it from its own perspective. The new conceptualization, referred to as "the resistance frame of thought" by Bilge (2010), considered the practice of hijab as a type of resistance to the western hegemony (Bedmar \& Palma, 2010; Brown, 2006). This frame especially became more popular after the incidents in France and Belgium, in which a number of girls were expelled from school due to their Islamic hijab. The girls' insistence on keeping their hijab was seen as their resistance to the norms imposed by the western hegemony.

Finally, a third conceptualization of hijab, which can be viewed as a middle ground between its western interpretation and Islamic one, is the school of thought known as Islamic Feminism. Islamic Feminism could be perceived as an amalgamation of western/mainstream feminism, postmodernism, and Islamic teachings. The main tenet of Islamic Feminism is that hijab, in the form practiced in Islamic settings, is not an Islamic ruling in itself, but an interpretation given by Islamic scholars, who are all men (Ahmad, 1992; Mernissi, 1991; Mir-Hosseini, 2006; Mojab, 2001; Razavi, 2006). In such a view, the patriarchy present in dominantly Muslim countries is not a feature of Islam, but an outcome of patriarchal interpretation of Islamic teachings. Therefore, Islamic feminists attempt to employ the discourse of Islam itself, in order to affect change in patriarchal interpretations of the religion, and in turn, move towards emancipation of Muslim women (Othman, 2006; Treacher, 2003). A primary argument among Islamic Feminists is that due to their use of Islamic discourse, they would not face severe confrontations from the state (Mojab, 2001; Terman, 2010). However, such attempts have not seen any significant success so far, and Islamic Feminism has remained a theoretical issue rather than a practical one, especially in more religiously conservative settings such as the Middle East (Afshar, 1998; Poya, 1999).

\section{New media, new potentials, new pitfalls}

There is no doubt that Web 2.0 revolutionized many aspects of the contemporary human existence. The unique features of Web 2.0, like its accessibility and being user-cantered, led to a drastic change in theorizations of media, power and resistance, public sphere, information flow, etcetera (Dahlgren, 2005, 2009).

Especially important for the present study is the changes made in relations of power and resistance by the rise of Web 2.0 and social networking sites. Traditionally, power was seen to be something only possessed and exerted by the sovereign, the monarch, and the ruling class, mostly through use of force and coercion (Tilly, 1991), or ideological state apparatus (Althusser, 2006), such as the educational system and the media. This one-sided view of power relations was challenged by poststructuralism, specifically by the works of Foucault on mental disorders (1994), prison systems (1995), and sexuality (1978). The new understanding of power viewed it as something not owned, but used. Moreover, the unidirectionality of power, being exerted only in a top-down fashion through coercion, underwent some changes. It is argued by Foucault that power is an inherent feature of discourses, flowing within them, and causing them to productively and creatively progress and develop (Foucault, 1978). Every individual enjoys some level of power, but it is the orders of the discourse which define how much power each subject has, and in which areas the subject can have power. Naturally, it was again the centralized institutions which enjoyed the highest level of power and institutionalize or naturalize it, but the new understanding argued that it is not merely force and coercion which ensures the exertion of power, yet it is what Foucault refers to as surveillance (Foucault, 1995; Kelsey \& Bennett, 2014). 


\section{FACEBOOK AS A TOOL FOR DISCURSIVE RESISTANCE: A CASE STUDY}

Foucault uses the Panopticon architectural metaphor of a prison to provide a visual image of his theory on how power relations work. In such a prison, the prison management and guards are located in a central tower, so that they can monitor all the prison cells, which are placed in a circle around the central tower. However, the prisoners cannot see the cells next to them, or the guards in the central tower. Therefore, the constant feeling of being observed by the guards leads to prisoners' internalizing the act of surveillance, hence monitoring their own behavior, without being coerced into doing so (Foucault, 1995).

This understanding of power relations was the dominant frame of thought since Foucault's writings. However, the rise and popularity of Web 2.0 posed significant challenges to this view. The panoptic view of power relations can be satisfactory only if the act of surveillance flows from the central tower towards the cells, without the prisoners seeing the guards. In contrast, the accessibility of the New Media provided the users with a much higher level of power (Kelsey \& Bennett, 2014). Individuals are no longer mere users, but are actively producing new content. This act of "produsage" (Bruns, 2007) enables social actors to monitor not only themselves and each other, but also the ruling class as well (Kelsey \& Bennett, 2014). Emergence of phenomena such as Wikileaks, online activism, the Arab Uprising, and the recent Iranian example which is the focus of this research is a result of this very culture of "produsage".

Kelsey and Bennett (2014), therefore, argue that the New Media should be seen not as panoptic anymore. Rather, they point to the synoptic and omnioptic nature of the New Media, in which the power relations are not unidirectional and linear anymore. Rather, individuals are now able to monitor the ruling class, themselves, and others all at the same time. It is due to this omnioptic aspect of the New Media that Iranian women have found a space to voice their dissent; a voice which had been silenced for three decades after the 1979 revolution. Nevertheless, one should not be hasty in optimistically concluding that these features of the New Media can lead to real changes in the civic and communal life of people (Boyd, 2008). After all, the online-offline gap is still out there, and without entering the 'real' life, any form of online activism can at best turn into slacktivism (McCafferty, 2011; Reardon, 2013), and an illusion of subversive act. The findings of our study point to instances of this divide between the virtual and real public spheres.

\section{Methodology}

This study was done under the umbrella term Critical Discourse Analysis, henceforth referred to as CDA. This problem-oriented multi-disciplinary approach to discourse aims to provide insights, critique, and criticism of discourses on a social problem, such as racism, discrimination, extreme nationalism, etc. (Fairclough \& Wodak, 1997; Fairclough, 2001; Reisigl \& Wodak, 2009). Although there are several approaches to CDA, all share the assumption that language is a social practice, bearing with it the network of knowledge, power, and ideologies (Gee, 2012; Wodak \& Meyer, 2009). Therefore, CDA scholars attempt to unravel the hidden and latent ideologies behind a discourse through an in-depth linguistic investigation of the text, the discursive practices and strategies, and the sociohistorical context in which certain discourses come into life (Fairclough, 2001).

The approach to CDA used in this research endeavour is the Discourse-Historical Approach, henceforth referred to as DHA. Developed by Reisigl and Wodak (2001), DHA deals with five heuristic questions of a) how social actors and actions are named and referred to (referential strategies), b) what qualities 


\section{FACEBOOK AS A TOOL FOR DISCURSIVE RESISTANCE: A CASE STUDY}

are attributed to social actors and actions (predication strategies), c) what argumentation schemes and process are used (argumentation strategies), d) how social actors and actions are intensified or mitigated (intensification and mitigation strategies), and e) how social actors and actions are perspectivized/framed (perspectivization strategies) (Khosravinik, 2010; Reisigl \& Wodak, 2001, 2009).

Rooted in the Grounded Theory tradition of research, and employing an interdisciplinary approach, DHA researchers recursively move back and forth between the text and theories, constantly reformulating and modifying the hypotheses and research questions to reach to an interpretation and explanation of the data under investigation (Reisigl \& Wodak, 2009). To do so, a DHA researcher often needs to consider a variety of middle-ground theories in philosophy, sociology, linguistics, discourse theory, psychology, and other theories relevant to the social problem under investigation (ibid.).

For the present study, over 500 Facebook posts were selected based on a criterion-based purposive sampling, taking into account criteria such as salience, frequency, relevance, representativity, intertextual/interdiscursive scope, and uniqueness. The data comes from the five most popular pages (with more than 20,000 'likes') created for the purpose of resisting compulsory hijab in Iran. The texts studied vary in length from one-sentence posts to multi-paragraph ones.

The objectives of this study, following the five heuristic questions in DHA, were to investigate how 'Self/Us' and 'Others/Them' were represented in the discourse. Moreover, the study was interested in identifying what argumentation schemes the discourse participants employ, and finally, to reach to a critique of the ideologies underlying the discourse. Informed by the Critical Theory, and more specifically by the Frankfurt School, the findings were then put into scrutiny, in order to theorize whether or not the resistance movement of the Iranian women could lead to practical (positive or negative) changes in the civic and communal life of the discourse participants.

\section{Findings}

The two major discourse participants or social actors present in the discourse under study can be categorized into "Self/Us" and "Them/Others". The category of "Self/Us" is seen as the discourse participants and social actors who are active in promoting the ideology of the Facebook pages. On the other hand, the "Them/Others" category consists of the antagonists of the discourse, who are the social actors against the movement and/or those enforcing compulsory hijab in Iran. Interestingly, the dichotomization of the discourse is not created through a sex-based categorization, but the social actors are categorized based on their ideological orientations. That is, the Self/Us consists of both men and women against compulsory hijab laws in Iran, while Them/Others are men and women who are in favour of such laws and practices.

\section{Representing Self/Us}

Expectedly, the Self/Us is mainly represented as a positive social actor. However, this highly positively represented social actor is often linked with negative experiences. In all references to the Iranian women in the Self/Us category, the representation is intensified using linguistic and discursive 


\section{FACEBOOK AS A TOOL FOR DISCURSIVE RESISTANCE: A CASE STUDY}

strategies which foreground the woman's being of a high educational, career, cultural, or political status. Honorifics often accompany a woman's name, and in almost all cases, a description is added to representation of an Iranian woman. Regarding men in the Self/Us category, the same strategy is often applied. That is, when introducing a man who is against the laws of compulsory hijab in Iran, the introduction is often accompanied by honorifics and positive descriptions of the man. Excerpt 1 exemplifies such uses.

- Golnaz Behgoo, social worker and children's rights activist...

- Narges Tavassolian, law expert, researcher, and a PhD student in law from University of London...

- $\quad$ Leila Sehhat, blogger and independent researcher...

Excerpt 1: honorifics used for positive self-representation

However, another discursive strategy employed in representation of Self/Us is a representation of Iranian women as victimized social actors. Negative experiences such as being arrested, intimidated, offended, harassed, threatened, and/or oppressed are often attributed to Iranian women. Table 1 enlists the strategies employed in representation of Us/Self as social actors with positive qualities and negative experiences.

Table 1: Positive qualities and negative experiences of Us/Self

\begin{tabular}{ll}
\hline Self/Us (Iranian Women) & Qualities Attributed \\
\hline Positive Qualities & Intellectual Qualities \\
& - free-thinker \\
& - modern \\
& - enlightened/intellectual \\
& - have prestigious jobs \\
& - educated \\
& Revolutionary Qualities \\
& - rebellious \\
& - brave \\
& - are not afraid \\
& - are hopeful of a bright future \\
& - will not give up
\end{tabular}

Negative Experiences

\section{Arrest}

- are arrested

- are insulted

- are jailed along with other criminals

\section{School/Career}

- face detention in school

- are humiliated

- cannot have managerial positions 
- deprived of jobs

- fired from jobs

- do not have equal pay

\section{Social Life}

- are raped

- are victims of violence

- are forced to be hypocrites

- ashamed of their sex

- fearful

- limited

- seen as men's property

- have to tolerate heat and cold

- suffer in a patriarchal society

- suffer from mental disorders

- are forced into self-censorship

- are deprived of basic rights

Representation of the negative experiences of Iranian women is mainly done through two discursive strategies: victimization and dramatization.

Victimisation, or representing a social actor through a 'victim narrative', plays a major role in perspectivizing or framing Us/Self. Iranian women are often represented as victims in the Iranian society. Table 2 provides a brief summary of the various themes employed to achieve the victimized representation of Iranian women.

Table 1: Victimisation

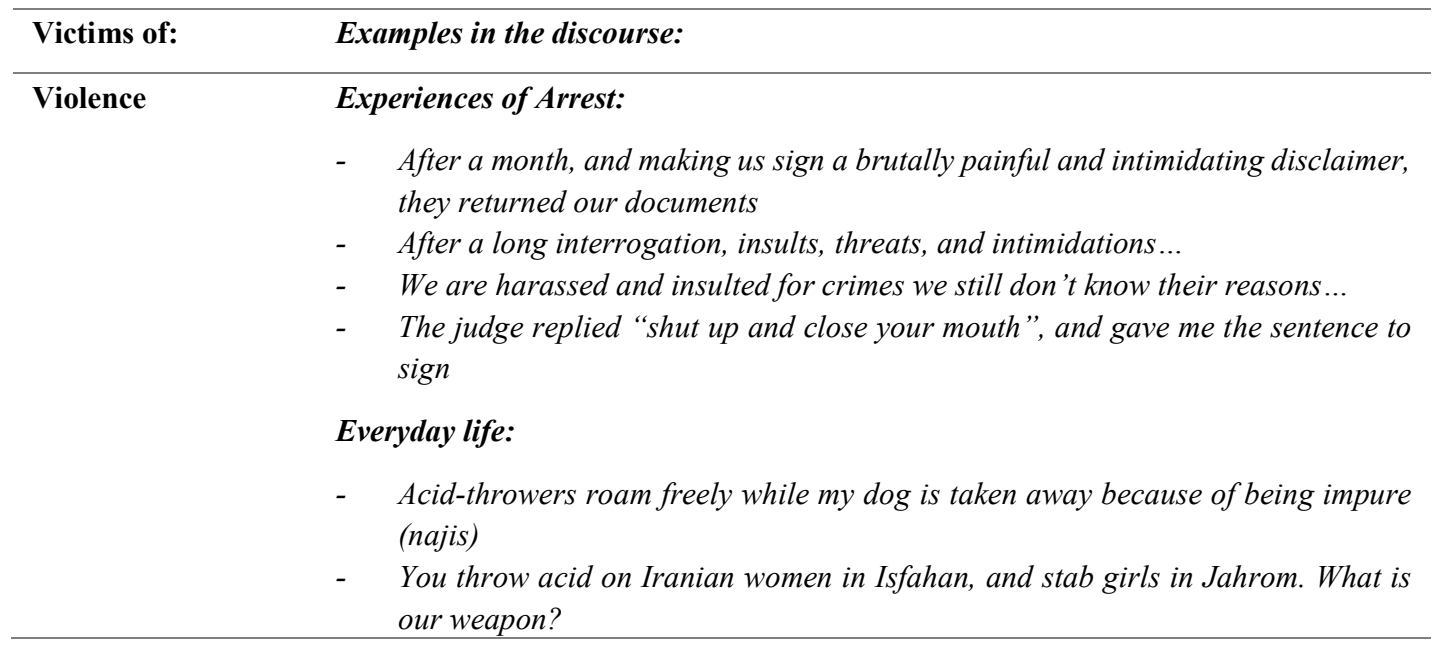




\section{FACEBOOK AS A TOOL FOR DISCURSIVE RESISTANCE: A CASE STUDY}

\begin{tabular}{|c|c|}
\hline & $\begin{array}{l}\text { - The strongest person on earth is the Iranian woman, who despite rapes, acid- } \\
\text { throwings, morality police, street harassments, murders, mugging, and thousands } \\
\text { of other dangers, still studies in this swamp. }\end{array}$ \\
\hline Puberty & $\begin{array}{l}\text { - Hijab means the long head cover I had to let hang on my breasts, so that my } \\
\text { classmates could not see my puberty... } \\
\text { - Do you know why I have back problems? Because I had to wear heavy manteaus } \\
\text { and carry heavy bags; I had to walk with a hunched back so that I could cover my } \\
\text { curves, which allegedly cause corruption in the society... } \\
\text { - My hunched back, which is there because of hiding the growth of my breasts, is } \\
\text { seen sooner than my feminine beauties... }\end{array}$ \\
\hline $\begin{array}{l}\text { Psychological } \\
\text { disorders }\end{array}$ & $\begin{array}{l}\text { - } \quad \text { I am depressed, like many other women... } \\
\text { - Compulsory hijab and morality police cause depression, anxiety, and feeling of } \\
\text { insecurity in women. } \\
\text { - So many mental and psychological problems among Iranian women are because } \\
\text { of compulsory hijab. }\end{array}$ \\
\hline
\end{tabular}

In addition to the victimization strategy, dramatization often intensifies the representation of Us/Them. In providing narratives of a woman's negative experiences regarding compulsory hijab in Iran, the narrative always contains highly affective/emotive descriptions, metaphors, metonymies, sarcastic remarks, and analogies. Examples of such can be seen in excerpt 2.

- How long should we bandage ourselves under this hot weather?

- $\quad$...something like a veil for the dead that I had to wear since childhood, called a dress!

- Our frail and small bodies, wrapped in manteaus, looking like a hockey player, was a ridiculous sight!

- In that chador, she looked the same from all angles!

Excerpt 2: Dramatization

Finally, self-identification of Us/Self as rebellious social actors is a concurrent theme within the discourse. The Iranian women under investigation often self-identify themselves as rebellious, revolutionary, non-conforming, and free-thinking agents. Expectedly, this strategy is only employed in representing women in the Us/Self category. Excerpt 3 provides some examples of this type of selfidentification.

- I have always used every opportunity to ditch the scarf, because hijab has never been my choice.

- Since childhood, I have always wanted to be the number one slut!

- I have been in opposition, in protest, since I was a child...

Excerpt 3: Rebellious self-identification

Representing Them/Others

Oikos: the Domestic Other. In the dichotomized perspectivization of the discourse, the antagonist is represented as the social actors who enforce or support the laws of compulsory hijab in Iran. Although there is a significant number of references to 'supporters' of compulsory hijab laws, the highest frequency of references to Them/Others belongs to representations of 'enforcers' of the laws, such as the police force, the members of the Basij para-military organization, or government officials. 


\section{FACEBOOK AS A TOOL FOR DISCURSIVE RESISTANCE: A CASE STUDY}

Them/Others are represented by three major themes and qualities attributed to them: sexual perversion, violence and aggression, and patriarchy and oppression. Table 3 refers to the discursive and linguistic strategies of representing Them/Others.

Table 3: Negative predication of Them/Others

\begin{tabular}{|c|c|c|}
\hline Others/Them & category-specific qualities & $\begin{array}{l}\text { Qualities Attributed } \\
\text { to both }\end{array}$ \\
\hline In General & $\begin{array}{ll}\text { - } & \text { Traditional } \\
- & \text { Yokels } \\
- & \text { Most important oppressors of } \\
& \text { women (family members) }\end{array}$ & $\begin{array}{ll}- & \text { Stupid } \\
- & \text { Mentally complexed } \\
- & \text { Pervert } \\
\text { - } & \text { Easily stimulated sexually } \\
- & \text { Retarded mentality }\end{array}$ \\
\hline Arresting Officers & $\begin{array}{ll}\text { - } & \text { Ugly } \\
\text { - } & \text { Have an 'unsightly' look } \\
\text { - } & \text { Aggressive } \\
\text { - } & \text { Violent } \\
\text { - } & \text { Impolite }\end{array}$ & $\begin{array}{ll}- & \text { Narrow-minded } \\
\text { - } & \text { Mock women } \\
\text { - } & \text { Insult women } \\
\text { - } & \text { Think they own women }\end{array}$ \\
\hline
\end{tabular}

The social actors enforcing compulsory hijab laws are often represented as sexually perverted men, who are easily aroused by seeing a woman's hair or body. When providing a narrative of one's arrest, there are references to the arresting officer's sexual perversion, leering, or sexual gaze. Excerpt 4 shows some examples of such.

- Every Iranian woman has at least once in her lifetime felt a perverted hand on her body, which was covered under layers of clothes and hijab.

- $\quad$...on the street, we had to tolerate the perverted leers of people, even with clothes on, and even at presence of our fathers...

- $\quad$...even the heavy shadow of the shameless leers at my forearms on the street...

- $\quad$ Suddenly one of the Basiji brothers jumped in front of us, and with his ghastly leer asked us...

Excerpt 4: Representation of Them/Others as perverts

Additionally, an element of violence and aggression is often attributed to Them/Others. This involves anything from an aggressive look, tone and voice, to physical violence, and sometimes extreme acts of violence such as acid-throwing or rape. Some instances of this kind can be seen in excerpt 5 .

- He walked to us in a threatening fashion, with a stick in his hands, and sent us to women's section like a herd of sheep, calling us with names only deserving his own family.

- One could only see the officers' eyes. One of them was older and was wearing glasses. She also had a very ugly and angry face. I heard her insulting the girls before us, and the other two would confirm what she said. When she saw us, she suddenly started shouting at us...

- $\quad$ One of the female officers insulted me, called me a prostitute... she slapped me on the mouth...

- $\quad$ On our way, we saw about ten ugly men walking on the sidewalk... those Basiji brothers raided there, like they were going to arrest drug dealers...

Excerpt 5: Representation of Them/Others as violent and aggressive 


\section{FACEBOOK AS A TOOL FOR DISCURSIVE RESISTANCE: A CASE STUDY}

Finally, references to patriarchal views are sometimes made in negative representations of Them/Others. This is especially true in references to a woman's family and relatives, such as one's husband, brothers, and uncles. In such cases, a woman's male family members are represented as traditionalist and patriarchal agents who believe women to be their property or possession.

The strategies of victimization and dramatization again come into play in negative representation of Them/Others. Almost in all cases of narrating one's experience of arrest, there is an emphasis on the woman's 'ordinary' clothes and makeup. This is followed by a detailed narrative of the aggression, intimidation, and violence involved in the course of the arrest. Again, emotive/affective language, and analogic, metaphoric, and metonymic references are the most concurrent strategies employed in dramatization of the narratives. The emphasis on 'ordinary' attire acts as a mitigating strategy through putting the blame solely on the arresting agent, and removing any blame from the woman. This is further done by employing mitigating adverbs, such as: 'any', 'nothing', 'just', completely', and 'very'. Excerpt 6 exemplifies these mitigation strategies.

- On that day, I was not wearing any form of makeup, and my face had nothing special to attract attention. I was wearing a dark blue overcoat, hanging down to my knees, and boots in which I had tucked my pants.

- I just had eye makeup that day.

- I should also mention that on that day, I was wearing a black scarf, manteau, and trousers. I had a completely simple attire.

- I remember throughout those years, I used to wear a very very dark green manteau...

Excerpt 6: Mitigating the Self and Intensifying the Other

This type of mitigation and intensification also acts as an argumentation strategy, through employing the logical fallacy of trajectio in alium, or blaming onto others. This will be discussed in its respective section.

Xenos: the Foreign Other. In most CDA studies, especially those done on discourses of racism and discrimination, there are two social actors present in the discourse: Us/Self, and Them/Others. The Xenophobia reported in such studies often involves Them/Others who belong to a geographically foreign setting, such as immigrants, foreign workers, and politicians of a country rather than one's own (KhosraviNik \& Zia, 2014; Reisigl \& Wodak, 2001). These actors are always negatively represented in such discourses, hence the term Xenophobia.

However, in the case of the discourse under study in this research, the discourse cannot be viewed as a purely dichotomized discourse, in which there is an Us versus Them struggle. Although the Us and Them categories explicitly and saliently represent the social actors belonging to the same geographical and socio-political context, there is a third social actor present in a significant number of the Facebook posts under study. This third social actor is often referred to when comparisons are made between an Iranian woman's experiences inside and outside Iran.

In references to a foreign setting, and especially a foreign man, there is an emphasis on the absence of any sort of ogle, leering, or sexual perversion. In other words, the Foreign Other is represented positively as an individual (man) who does not leer at a woman, and poses no threat to her, mentally or physically. A feeling of relief, freedom, and safety is often reported in the presence of this Foreign Other. Excerpt 7 refers to some examples of such: 


\section{FACEBOOK AS A TOOL FOR DISCURSIVE RESISTANCE: A CASE STUDY}

- Beautiful young women, with bodies as white as marbles, were walking around the pool happily. No perverted leer would follow them...

- $\quad$ There is no compulsory hijab here, and more importantly, nobody ever leers at nobody...

- My first experience in a university abroad, and my most beautiful experience, gave me a feeling of freedom and humanity...here I see how half-naked Swedish girls sit with hijabi Pakistani women and burqa-wearing Somalian students...

- Here, I'm happy that I'm a woman...Nobody looks at me like a sex slave, whether I go out totally covered, or in a bikini...

Excerpt 7: Positive Foreign Other

Having noted this, we argue that the discourse under investigation should not be viewed as a dichotomized one, but rather, a "trichotomized" discourse, in which three main social actors are present: a positive Self/Us, a negative Domestic Other/Them (Oikos), and a positive Foreign Other/Them (Xenos). This will be discussed in more detail in the following sections.

\section{Argumentation strategies}

An analysis of the argumentation strategies employed in a discourse acts as both a triangulatory practice and a means to discover the latent and implicit ideologies in a discourse (Reisigl \& Wodak, 2001, 2009). Our analysis of argumentation strategies, following DHA guidelines, is done against the ten rules of rational argumentation by van Eemeren and Grootendorst (van Eemeren \& Grootendorst, 1992, 2004; van Eemeren, 2002). It is through this step of analysis that one can investigate a discursive practice's rationality, intra-discursive contradictions, motivating factors, and ideological slants.

KhosraviNik (2014) cleverly points out the fact that in a study done on social media, especially on discourses of public Facebook pages, one should not overlook the point that the Facebook pages under investigation are usually a gathering of like-minded people with explicit ideological viewpoints, and therefore there is often an "on-the-record bias" present in these discourses. He argues that an analysis of argumentation, therefore, should not be seen as one done on mainstream media and political speeches, in which such ideologies are often interwoven in the text, and are latently and implicitly expressed (ibid.). However, argumentation analysis seems to still be a very useful and valuable tool, since it can reveal the intra-discursive coherence and contradictions. In other words, although the researcher knows, a priori to the study, what ideologies are put forward in a public Facebook page created for a certain purpose, an analysis of argumentation strategies is still necessary to discover whether or not such ideologies are taken up through a rational procedure. Certainly, there is a difference between the argumentation strategies employed to reach to a racist or discriminatory conclusion, and those used to promote human or animal rights.

In the case of the discourse under investigation in this study, a striking feature discovered through the analysis of argumentation is a highly affective, rationally fallacious, and reactionary motive behind the discourse participants' stance against the compulsory hijab in Iran. Of the 500 Facebook posts analysed, only less than 30 of them conform to rational argumentation principles and warranted claims. That is, the move from premises to conclusions is almost always fallaciously done, employing various logical fallacies. 


\section{FACEBOOK AS A TOOL FOR DISCURSIVE RESISTANCE: A CASE STUDY}

The rationally valid arguments and claims in the discourse appeal to universal human rights as their building blocks of premises. By stating an acceptance of human rights, the individual then moves to conclude that because compulsory hijab laws deprive women of one of their basic rights, which is the freedom of expression, they need to be abolished. In other words, the move from the premise to the conclusion, the warrant and assumptions, and the conclusion itself can be seen as rationally valid, even though one might challenge each part of the whole claim.

However, such rationally valid claims are only seen in a very small number of the Facebook posts. In the majority of cases, the arguments are emotively loaded and rationally fallacious. The fallacy of argumentum ad passiones, or argument using emotions, is the most frequently seen case in the discourse. Various forms of this fallacy are employed, such as argumentum ad misericordiam (appeal to misery) and argumentum ad metum (appeal to fear). In such cases, the claim is that since the laws and practices of compulsory hijab put Iranian women under a lot of mental and physical pressure, they should be abolished. The most concurrently seen examples of such pressures are the previously mentioned "victimization" and "dramatization", especially issues of wearing hijab in hot weather, the long-lost dream of wind blowing in one's hair, and the physical distress the heavy clothing puts on women's posture. Excerpt 8 shows a few examples of these themes.

The fallacy of these arguments lies in the fact that rationally, there is no link between the (un)desirability of a practice and its logical validity. That is, simply because an action produces undesirable outcomes does not mean that the action needs to be avoided. More specifically, the undesirability of wearing hijab in hot weather does not rationally warrant the claim that such laws need to be abolished. Such a claim, even if accepted for the sake of argument, applies only to the summer time, which lasts for two to four months in most Iranian cities. As for other themes, such as heavy clothing and its physical toll, one might argue that women could use lighter fabrics and still conform to laws of hijab in Iran, since there are no guidelines on the weight of the fabrics to be worn in the laws.

Hot weather:

- Every time my body burns under my sweaty clothes in the summer heat, I remember my deprivations...

- I had to walk under the 40-degree summer sun.

- $\quad$ The hot days of final exams in June, when tolerating the heat with my wind-and-rain-deprived neck was more stressful than the exams...

Wind in hair:

- I, too, like to enjoy the caress of wind in my hair.

- This is Iran ... the feeling of the wind blowing through every strand of hair is a girl's biggest dream...

- I shave my head so that I might forget the craving for wind blowing in my hair...

- When you have lived for nearly three decades while you have never felt the wind dancing in your hair...

\section{Excerpt 8: Appeals to undesirability of hijab}

Another frequently seen logical fallacy in the discourse is argumentum ad hominem. Personal attack, or attacking the opponent rather than the claim, is often used in the Facebook posts to conclude that because people who promote the laws of compulsory hijab are sexual perverts, violent oppressors, 


\section{FACEBOOK AS A TOOL FOR DISCURSIVE RESISTANCE: A CASE STUDY}

and/or narrow-minded, such laws need to be abolished. Another type of this fallacy, known as poisoning the well, is sometimes used to prevent counter-arguments from the opponents. However, rational argumentation requires the claimants to only oppose the arguments rather than the opponent. That is, the personal characteristics of a claimant are irrelevant to the claim (Bennet, 2012; van Eemeren \& Grootendorst, 2004).

Finally, there is a significant number of other fallacies, most notably trajectio in alium (projection onto others), bifurcation, argumentum ad populum (appeal to population), and argumentum ad verecundiam (appeal to authority) in the discourse. Table 4 summarizes these to maintain brevity.

Table 4: Logical fallacies in the discourse

\begin{tabular}{ll}
\hline Fallacy & Simplified Claim \\
\hline Trajectio in alium & $\begin{array}{l}\text { Women are not to blame. It is men who have the problem. } \\
\text { Therefore, compulsory hijab must be abolished. }\end{array}$ \\
\hline Bifurcation & $\begin{array}{l}\text { Since compulsory hijab negatively affects women's welfare, } \\
\text { the only other option is abolishing it. }\end{array}$ \\
\hline Argumentum ad populum & $\begin{array}{l}\text { Because the movement has received widespread international } \\
\text { attention, it is righteous. }\end{array}$ \\
\hline Argumentum ad verecundiam & $\begin{array}{l}\text { Because women and men with a high social status defend the } \\
\text { movement, it is righteous. }\end{array}$ \\
\hline
\end{tabular}

Comparing the high number of fallacious and reactionary claims made against compulsory hijab in Iran and the very low number of rational claims points to the intra-discursive contradictions inherent in the discourse under study. The point made here is not that because the claims are mostly fallacious, the conclusions are wrong. Rather, our emphasis is on the fact that the discourse participants in the resistance movement are not driven by ration and logic, but by affective motivating factors. Simply put, the resistance to compulsory hijab in Iran seems to not be formed because the individuals believe it is rationally wrong. On the other hand, it appears to be mainly formed due to negative experiences and personal preferences. In the following section, it will be discussed how this reactionary and affective motivation can act self-destructively against the movement.

\section{Discussion}

\section{Reactance theory}

The Occidentalist, rebellious, and reactionary self-identification of the Iranian women can be perceived as an inevitable psychological reaction to the series of repressive state apparatuses used by the Iranian government in the last three decades. The coercive enforcement of compulsory hijab, combined with a failure in ideological naturalization of such worldviews, has led to a productive and creative manifestation of resistance within the discourse. The reactance theory, put forward by Brehm in 1966, posits that human beings tend to favour the possible options of which they are deprived, even though they might not opt for such options if left in complete control and freedom (Brehm, 1966; Miron \& Brehm, 2006). Experimental and controlled psychological studies done in various contexts confirm such tendencies (Johnson \& Buboltz, 2000). Viewing the resistance discourse of the Iranian women on 


\section{FACEBOOK AS A TOOL FOR DISCURSIVE RESISTANCE: A CASE STUDY}

the Facebook pages under this light could be seen as another example of the theory of reactance. In cases, there is a direct admission of this reactionary nature, as seen in Excerpt 9:

- When I left Iran forever, I ditched my manteau in the garbage bin on the street. This was what the government and society forced me to wear, and I threw it in the garbage bin and returned it to the society.

- $\quad$...the day I threw my last scarf in a suitcase and mailed it to Iran.

- $\quad$ Since then [the day she was arrested], I open my scarf on the street whenever I can, even for a few minutes...

- From the next day on, a type of hostility and stubbornness grew in me. This arrest became a turning point in my views about what I had never thought about before: nakedness!

Excerpt 9: Psychological reaction to coercive measures

A parallel view, yet from the theoretical framework of sociology and philosophy through the works of Michel Foucault, explains this tendency in a broader framework. In a Foucauldian understanding, resistance is an inevitable outcome of the existence of power relations within a discourse (Bartky, 1988; Foucault, 1978). His famous quote, "where there is power, there is resistance" (Foucault, 1978 p.95), could be seen in light of the reactance theory, especially at an agent-based, individual level, which in turn leads to social movements and discourses. Perhaps, it is due to this sub-conscious process of reactance that the discourse is full of emotive/affective rationalizations against compulsory hijab, with little space given to rational argumentation.

The point here is not to take up a rationalist bias, dismissing all other human motivating factors, as is the case in many studies done on social problems (Dahlgren, 2005). However, we argue that while there is a high value to affective motives, they cannot and should not be the only driving forces of a movement, simply because emotions are prone to manipulation or wearing off. Additionally, although the affective motives can effectively gather individuals together in a public sphere, it is rationality which can help the collective force find its appropriate course of actions, affect change, and achieve its desired objectives. Motivation might gain a boost through affects, yet strategizing definitely requires rational thought. What turns a "trend" into a "social movement", thus preventing it from wearing off and disappearing, is the rationality flowing within the discourse. Otherwise, any trend would face an eventual demise.

\section{Xenophobia, Xenophilia, Oikophobia}

The trichotomized aforementioned discourse along with the salient features of the discourse point to a significant ideological perspective of the discourse participants. It was shown how the negative representation of the Domestic Other serves to present a sense of dislike and fear of people from one's own cultural context. This cannot be referred to as xenophobia in its common sense in the literature, since xenophobia often refers to a fear or dislike of people from other geographical contexts. Therefore, we propose a more appropriate term, "Oikophobia", for the discourse under study. The negative representation, in this discourse, is not aimed at the foreigners, but at people from one's own country. In some cases, this Oikophobia even goes to its extremes, taking the form of misandry and disliking all men in general. Excerpt 10 shows a few examples of such:

- $\quad$...but growing up in that society caused an inner hatred of men in me.

- $\quad$ I could no longer trust any man... 


\title{
FACEBOOK AS A TOOL FOR DISCURSIVE RESISTANCE: A CASE STUDY
}

- I still fear men. I escape from any manly look...

\author{
Excerpt 10: Misandry
}

On the other hand, the Foreign Other, which is positively represented, belongs to an extra-discursive setting. That is, this social actor is not directly present in the discourse of compulsory hijab inside the Iranian context. Praising the Foreign Other, and self-identification with the ideologies of this foreign xenos, which we refer to as Xenophilia, points to the ideological orientation of these Iranian women in favor of the western feminist conceptualization of hijab, previously mentioned as 'the submission frame' of thought (Bilge, 2010). In such an understanding, hijab is seen as an oppressive, patriarchal notion.

Therefore, although the Foreign Other cannot be seen as belonging to Us/Self, mainly due to the different socio-cultural contexts, it is regarded as being an ally, a social actor in tune with ideologies of Self/Us. However, stopping at this point, and agreeing with the western feminist understanding of the situation, would lead to a reductionist and simplistic understanding of the context. The Occidentalist discourse of the activist Iranian women does not take into account the complexities of the Iranian culture and political system. Moreover, the bigger picture of globalization introduces newer issues and threats to the movement. These will be discussed in the following sections.

\section{Illusion of Resistance}

It was shown how the women in the Facebook pages self-identify as rebellious, resisting, revolutionary, and pro-freedom. However, two important factors should not be ignored in this regard: the notions of "Peasant Resistance" and "Slacktivism".

Scott (1987) shows how ordinary people, especially the marginalized groups, resort to some form of resistance to the dominant ideology in their everyday practices. Nevertheless, he notices that these acts of resistance are done in ways which attract minimal confrontation from the dominant groups (Tilly, 1991). Scott refers to this strategy as "peasant resistance". In his later works, he argues that almost all forms of resistance by people could be seen as instances of peasant resistance, employing strategies which do not pose any serious hardship or threat to the individual (Mitchell, 1990).

The same principle applies to the resistance movement of the Iranian women in this research. The Facebook pages created by these women are full of revolutionary and rebellious texts, condemning compulsory hijab, offending the government officials, criticizing the police force, etc. However, all such acts are solely limited to the online public sphere, with almost no manifestation in the civic and communal life of Iranian women. This online-offline gap, which Boyd refers to regarding the Arab Uprisings (Boyd, 2008), is deeply felt in the discourse under study. Even in the case of the Stealthy Freedoms page, in which Iranian women post their photos without the conventional and governmentally approved hijab, the "peasant resistance" can clearly be seen. Although this page has received widespread positive media attention in the west, it has not been able to achieve any practical results inside Iran. A quick survey of the photos posted on this page shows that the majority of the photographs are taken either in the nature or in empty streets where there is no danger of being confronted by the police. Moreover, there are many other photographs on the page depicting women from behind, so that their face cannot be recognized by anybody. The "peasant resistance" on these 


\section{FACEBOOK AS A TOOL FOR DISCURSIVE RESISTANCE: A CASE STUDY}

Facebook pages challenges the optimistic perception of the movement by the public, the media (Saul, 2015; Threadgould, 2015), academics (Karimi, 2015; Koo, 2014; Novak \& Khazraee, 2014), and the activists themselves. In such a setting, the online public sphere has led to the creation of a comfortable space to voice dissent, yet maybe so comfortable that all movements have remained limited to the boundaries of the online, virtual world. The situation inevitably reminds one of Slavoj Zizek's infamous joke and argument about the illusionary and futile movement of dissidents against the ruling party (Zizek, 2009).

What is achieved in reality, where these women actually live, go to work, have social experiences, and face the discriminatory practices, is simply a number of 'clicks', 'likes', and 'sharing of content' on the web. Such illusionary acts are merely acts of "slacktivism" (McCafferty, 2011; Reardon, 2013), providing the discourse participants a sub-conscious relief of "doing something", while in reality, nothing has been done. Although some awareness might be raised by the movement, unless the acts of resistance enter the domain of the 'real', rather than the 'virtual', no practical results will be achieved.

\section{The futility of the movement}

An optimist would argue there is a strong sense of scepticism in the above lines. Therefore, and for the sake of argument, we will discuss the different possible outcomes of the resistance movement under the socio-political context of Iran, to evaluate whether the movements can be of any practical value. The movement started by these Iranian women can witness one of the three possible scenarios; it can succeed in abolishing the laws of compulsory hijab in Iran, it can fail, or the battle will continue without achieving success or accepting failure.

A problem inherent in the movement, without considering the possibilities facing it, is an inversion of priorities. In a country where there is widespread discrimination against women, such as lower salaries than their male counter-parts, child marriage, lack of divorce rights, etc., the problem of compulsory hijab does not seem to be of a high priority. That is not to undermine the significance of this discriminatory practice or the resistance movement. However, the problem shows itself when one considers a dearth of movements against other discriminatory practices against women in Iran. It seems that women's rights activists have not put as much efforts in solving these practices as to challenge compulsory hijab.

Secondly, there is the aforementioned issue of the higher importance of the Islamic rules, values and norms than the public demands in the Iranian political hierarchy. Therefore, it is expected that demands regarding reformations of laws related to Islamic teachings would face strong objections on the side of the Iranian government. Hypothetically, even if the president or the parliament ask for a reformation of such laws, the non-democratic organizations located above them in the Iranian political hierarchy, chosen directly by the Supreme Leader, would not allow these reformations to be manifested. Moreover, the fact should not be ignored that hijab, as an Islamic practice, has enabled more Iranian women to enter social domains. By conforming to the practice of hijab, more and more Iranian women have been able to find jobs, enjoy higher education, and have an active role within the Iranian society (Afary \& Anderson, 2005). Therefore, it would seem more practical and perhaps important to focus on achieving equality in the work setting, for instance, rather than abolishment of hijab laws. Again, this is not to say that the movement against compulsory hijab should be forgotten. However, it is argued 


\section{FACEBOOK AS A TOOL FOR DISCURSIVE RESISTANCE: A CASE STUDY}

that parallel movements, which can be advantageous to a higher number of Iranian women, should also be formed. Unfortunately, this has not been the case so far. That is why the present resistance movement seems to have inverted the priorities by focusing on an issue of a lesser significance.

Nevertheless, there is no denying that this movement has been around for the past couple of years. Therefore, it is wise to consider the three possible outcomes which could be achieved.

\section{Three scenarios:}

A continuous battle against the laws and practices of compulsory hijab would give rise to the possibility of a continuous ignorance of the other aforementioned discriminatory practices against women. If the present situation continues without reformations in activist policies, and if the primary focus continues to be put on compulsory hijab laws, other (and perhaps more important issues) which could be addressed quite more easily and with less state confrontation would continue to be overlooked, adding to the dire situation of the Iranian women. Therefore, unless feminist activists in Iran start to take up a more holistic approach, no desirable outcomes would be gained out of a continuous battle. This is of course assuming that a continuous struggle would not tire out the individuals.

A more disturbing outcome of the resistance movement is the possibility of its failure. Judging by other forms of online activism and trendy topics, it is not unlikely that the Facebook pages, and the resistance movement, witness a decline in public interest, simply due to the absence of any achievements or tangible results. This decline is quite likely, especially given the reactionary and affective nature of the movement rather than being rationally motivated. A case of this downfall in the public interest can be seen in the most well-known Facebook page created for this resistance movement. Although Stealthy Freedoms attracted more than 600,000 'likes' in the first few months of its formation, only 200,000 more 'likes' have been added to this number during the next two years of the page's life. An outlook of a reduction in public interest is far from desirable, since it could lead to a collective sense of disappointment among the Iranian women active in areas of discrimination against women. The hopelessness created as a result of the failure of the movement would prevent the emergence of similar movements against other discriminatory practices, which are perhaps even more important than the issue of compulsory hijab.

In a very optimistic view, however, one would argue that the anti-hijab movement can succeed in achieving its objectives, and the laws of compulsory hijab in Iran will be abolished, or at least changed, in the near or far future. Firstly, it is worth noting that such an optimistic view, which is often shared by the western media and the activist Iranian women themselves, is unrealistic, simplistic, and atomistic. The complexity of the Iranian political system ensures that even if the public demands a reform in the laws, it will not happen if the demand is against the Islamic (Shi'a) interpretations of the ruling elite. Institutions such as the Guardian Council and the Expediency Council have been incorporated in the Iranian political hierarchy to filter the contradictions between democratic and theocratic values in favor of Islamic theocracy. Consequently, it is hopeful that the laws will change as there are a considerable number of people demanding for that. So, it is far from the reality of political decision making in Iran. Moreover, given the population of Iranian women (approximately 35 million), and the low penetration ratio of the internet in Iranian cities, the number of followers of this movement cannot be seen as considerable by any statistical measure. As it was pointed out, the highest number of followers a Facebook page in this movement has attracted is less than 1 million. 


\section{FACEBOOK AS A TOOL FOR DISCURSIVE RESISTANCE: A CASE STUDY}

Nevertheless, even if the movement succeeds in a miraculous way, and the laws of compulsory hijab in Iran are abolished, what would be achieved will be self-contradictory at best. It was shown how the Iranian women's discourse on the Facebook pages points to a reactionary feeling against the sexual gaze aimed at women. One recurrent argument in the discourse is that the Domestic Others/Them view women as objects of sexual desire, and want them to be covered up to protect the morality and modesty of the society, while reserving them for exclusive pleasure of their husbands. However, the insistence of these Iranian women on abolishment of compulsory hijab laws, and in turn the freedom to reveal one's body in public (Dickenson, 2007), is heavily under the mainstream global human rights value of one's control over his/her body. Interestingly, the very feminist discourse these pages are appealing to is itself criticized for being patriarchal, leading to objectification of women's bodies. It has been argued by several feminist scholars that the 'revealed' female body is a construct of patriarchal views, which aim to put the female body and sexuality under the 'male gaze', turning it into an object of sexual desire (Berger, 1972; Sutton, 2007). Ironically, by insisting on the discourse of 'revealing the body', these Iranian women are willingly accepting to be objects of sexual desire and the male gaze. The only point of difference between the ideologies of the Iranian state and the resistance movement is on exclusivity of the female body. While the Iranian government reserves the female body for the exclusive sexual pleasures of the husband, the resistance movement attempts to turn it into a public showcase for all men. In other words, even if the movement succeeds in its goals, what would be achieved will again be an objectified, sexualized woman, yet in a different ideological perspective. In any case, the female body would be objectified and commodified, and a woman would only be identified as a bodily identity, without taking into account other aspects of being a woman or a human being (Cover, 2003; Halewood, 2008; Parry, 2012; Sharp, 2000).

\section{Conclusion}

By investigating a recent and unique resistance movement in the online public sphere, this study examined the discursive strategies and ideological perspectives of online activists, in order to come to a critique and criticism of the movement, and further theorize the efficacy of online movements in achieving real civic and communal changes in their contexts. It is argued that there is a strong connection between the online and offline worlds in emergence of such movements. However, although it is the real experiences in the civic life that bring about resistance movements in the virtual sphere, the reverse seems to not be true. That is, the resistance is created due to a reaction to the 'real', but does not manifest itself in the civic life. Rather, the illusion and comfort of resisting the 'real' in the 'virtual' has restricted the movement in the online public sphere, without achieving any practical outcomes.

Before one can come to a conclusion about the strength or weakness of a particular online social movement, we argue that the contextual considerations of the given issue need to be investigated. The optimistic aura surrounding the online resistance movement of Iranian women to laws of compulsory hijab does not seem to take the context of the situation into account. Unless the pioneers of this movement make a reformation in their policies, no bright future can be envisioned for the movement. Unfortunately, however, the clues point to an otherwise journalistic, reductionist, and irrational bias in the movement, shared by the members and the administrators of the Facebook pages under study. This further pictures a grim prospect for the movement. 


\section{FACEBOOK AS A TOOL FOR DISCURSIVE RESISTANCE: A CASE STUDY}

\section{References}

Afary, J., \& Anderson, K. B. (2005). Foucault and the Iranian revolution: Gender and the seductions of Islamism. Chicago: University of Chicago Press.

Afshar, H. (1998). Islam and feminism: an Iranian case-study. London: Macmillan Press.

Ahmad, L. (1992). Women and Gender in Islam. New Haven: Yale University Press.

Al-Balagh. (2015). The Islamic Hijab (veil). Retrieved from http://www.al-islam.org/islamic-hijab-albalagh

Althusser, L. (2006). Ideology and ideological state apparatuses (notes towards an investigation). In S. Aradhana \& A. Gupta (Eds.), The anthropology of the state: A reader (1st ed., pp. 86-111). Malden: Blackwell Publishing.

Bartky, S. L. (1988). Foucault, femininity, and the modernization of patriarchal power. In L. Quinby \& I. Diamond (Eds.), Feminism and Foucault: Reflections on Resistance (pp. 61-86). New England: Northeastern University Press.

BBC Persian. (2014, July 28). Morality Police. Retrieved from http://www.bbc.co.uk/persian/iran/2014/07/140728_142_vid_ir_dress_code.shtml

Bedmar, V. L., \& Palma, V. C.-D. (2010). The Muslim veil controversy in French and Spanish schools. Islam and Christian-Muslim Relations, 21(1), 61-73. http://doi.org/10.1080/09596410903481861

Bennet, B. (2012). Logically Fallacious. Sudbury, MA: eBookit.

Berger, J. (1972). Ways of Seeing. London: BBC and Penguin Books.

Bilge, S. (2010). Beyond Subordination vs. Resistance: An Intersectional Approach to the Agency of Veiled Muslim Women. Journal of Intercultural Studies, 31(1), 9-28. http://doi.org/10.1080/07256860903477662

Boyd, D. (2008). Can social network sites enable political action? International Journal of Media and Cultural Politics, 4(2), 241-244. http://doi.org/10.1386/macp.4.2.241_3

Brehm, J. W. (1966). Theory of Psychological Reactance. Academic Press Inc.

Brown, K. (2006). Realising Muslim women's rights: The role of Islamic identity among British Muslim women. Women's Studies International Forum, 29(4), 417-430. http://doi.org/10.1016/j.wsif.2006.05.002

Bruns, A. (2007). Produsage : Towards a Broader Framework for User-Led Content Creation. Knowledge Management, 6(8), 99-106. http://doi.org/http://doi.acm.org/10.1145/1254960.1254975

Cover, R. (2003). The Naked Subject: Nudity, Context and Sexualization in Contemporary Culture. Body and Society, 9(3), 53-72.

Dahlgren, P. (2005). The Internet, Public Spheres, and Political Communication: Dispersion and Deliberation. Political Communication. http://doi.org/10.1080/10584600590933160

Dahlgren, P. (2009). Media and Political Engagement: Citizens, Communication, and Democracy. Cambridge: Cambridge UP.

Dickenson, D. (2007). Property in the Body: Feminist Perspectives. Cambridge: Cambridge University Press.

El Guindi, F. (1999). Veil: Modesty, Privacy and Resistance. Oxford: Berg.

Fairclough, N. (2001). Language and Power. Language in Social Life Series (2nd ed.). London: Routledge.

Fairclough, N., \& Wodak, R. (1997). Critical Discourse Analysis. In T. A. van Dijk (Ed.), Discourse as Social Interaction (pp. 258-284). London: Sage Publications.

Foucault, M. (1978). The History of Sexuality Vol.1: An Introduction. New York: Pantheon Books.

Foucault, M. (1994). The Birth of the Clinic: An Archaeology of Medical Perception. New York: Vintage Books. 


\section{FACEBOOK AS A TOOL FOR DISCURSIVE RESISTANCE: A CASE STUDY}

Foucault, M. (1995). Discipline and Punish: The Birth of the Prison (2nd ed.). Vintage Books. Gee, J. P. (2012). Discourse Analysis. In Social Linguistics and Literacies: Ideology in Discourses, Critical Perspectives on Literacy and Education (4th ed., pp. 112-127). New York: Routledge.

Halewood, P. (2008). On Commodification and Self-Ownership. Yale Journal of Law \& the Humanities, 20(2), 131-162. Retrieved from

$\mathrm{http}: / /$ content.ebscohost.com/ContentServer.asp? $\mathrm{T}=\mathrm{P} \& \mathrm{P}=\mathrm{AN} \& \mathrm{~K}=502049110 \& \mathrm{~S}=\mathrm{R} \& \mathrm{D}=\mathrm{ofm} \&$ EbscoContent=dGJyMMvl7ESeqa44yOvqOLCmr0qep7VSsqq4SrSWxWXS\&ContentCustom er=dGJyMPPt54vhset55+S5febl8YwA Inhttps://ezproxy.lib.uwm.edu/login?url=http://search.eb scohost.com/login

Hasan Miri, F. (2013). All Rohani's Promises to Iranian Women. Retrieved July 13, 2015, from http://khabaronline.ir/detail/299121/society/family

Hoodfar, H. (1993). The veil in their minds and on our heads: The persistence of colonial images of Muslim women. Resources for Feminist Research, 22(3/4), 5-18.

Johnson, P., \& Buboltz, W. C. (2000). Differentiation of Self and Psychological Reactance. Contemporary Family Therapy, 22(1), 91-102.

Justice for Iran. (2014). Thirty-five Years of Forced Hijab: The Widespread and Systematic Violation of Women's Right in Iran. Retrieved from http://justice4iran.org/english/wpcontent/uploads/2014/03/Hejab-Report-JFI-English.pdf

Karimi, S. (2015). Iranian Women's Identity and Cyberspace: Case study of Stealthy Freedom. Journal of Social Science Studies, 2(1), 221-233.

Kelsey, D., \& Bennett, L. (2014). Discipline and resistance on social media: Discourse, power and context in the Paul Chambers "Twitter Joke Trial." Discourse, Context and Media, 3(1), 37-45. http://doi.org/10.1016/j.dcm.2013.12.001

Khosravinik, M. (2010). Actor Descriptions, Action Attributions, and Argumentation: Towards a Systematization of CDA Analytical Categories in the Representation of Social Groups. Critical Discourse Studies, 7(1), 55-72.

KhosraviNik, M., \& Zia, M. (2014). Persian Nationalism, Identity and Anti-Arab Sentiments in Iranian Facebook Discourses. Journal of Language and Politics, 13(4), 755-780.

Koo, G. Y. (2014). Women as Subject of Defiance and Everyday Politics of Hijab as Dress Code in Modern Iran. Asian Women, 30(4), 29-51.

Macdonald, M. (2006). Muslim Women and the Veil. Feminist Media Studies, 6(1), 7-23. http://doi.org/10.1080/14680770500471004

Mahmood, S. (2005). Politics of Piety: The Islamic Revival and the Feminist Subject. Princeton and Oxford: Princeton University Press.

McCafferty, D. (2011). Activism vs. Slacktivism. Communications of the ACM, 54(12), 17. http://doi.org/10.1145/2043174.2043182

Mernissi, F. (1991). Women and Islam: An Historical and Theological Enquiry. Oxford: Basil Blackwell Ltd.

Mir-Hosseini, Z. (2006). Muslim Women's Quest for Equality : Between Islamic Law and Feminism. Critical Enquiry, 32(4), 629-645.

Miron, A. M., \& Brehm, J. W. (2006). Reactance Theory - 40 Years Later. Zeitschrift Für Sozialpsychologie, 37(1), 9-18. http://doi.org/10.1024/0044-3514.37.1.9

Mitchell, T. (1990). Everyday Metaphors of Power. Theory and Society, 19(5), 545-577. http://doi.org/10.1007/BF00147026

Mojab, S. (2001). Theorizing the Politics of Islamic Feminism. Feminist Review, 69(1), 124-146.

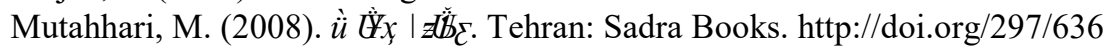

Mutahhari, M. (2015a). Jurisprudence and Its Principles. Retrieved from http://www.alislam.org/jurisprudence-and-its-principles-ayatullah-murtadha-mutahhari 


\section{FACEBOOK AS A TOOL FOR DISCURSIVE RESISTANCE: A CASE STUDY}

Mutahhari, M. (2015b). The Islamic Modest Dress. Retrieved from http://www.al-islam.org/theislamic-modest-dress-ayatullah-murtadha-mutahhari

Novak, A. N., \& Khazraee, E. (2014). The Stealthy Protester: Risk and the Female Body in Online Social Movements. Feminist Media Studies, 14(6), 1094-1095.

Othman, N. (2006). Muslim Women and the Challenge of Islamic Fundamentalism/Extremism: An Overview of Southeast Asian Muslim Women's Struggle for Human Rights and Gender Equality. Women's Studies International Forum, 29(4), 339-353. http://doi.org/10.1016/j.wsif.2006.05.008

Parry, B. (2012). Economies of Bodily Commodification. In T. J. Barnes, J. Peck, \& E. Sheppard (Eds.), The Wiley-Blackwell Companion to Economic Geography (pp. 213-225). WileyBlackwell. http://doi.org/10.1002/9781118384497.ch13

Poya, M. (1999). Women, Work, and Islamism: Ideology and resistance in Iran. London: Zed Books.

Razavi, S. (2006). Islamic Politics, Human Rights and Women's Claims for Equality in Iran. Third World Quarterly, 27(7), 1223-1237. http://doi.org/10.1080/01436590600933362

Reardon, S. (2013). Does Online "Slacktivism" Actually Do More Harm than Good? New Scientist, 218(2915), 24. http://doi.org/10.1016/S0262-4079(13)61115-X

Reisigl, M., \& Wodak, R. (2001). Discourse and Discrimination: Rhetorics of Racism and AntiSemitism. London: Routledge.

Reisigl, M., \& Wodak, R. (2009). The discourse-Historical Approach (DHA). In R. Wodak \& M. Meyer (Eds.), Methods of Critical Discourse Analysis (2nd ed., pp. 87-121). Sage.

Saul, H. (2015). My Stealthy Freedom: Women in Iran Sep up Hijab Campaign by Filming Themselves Walking in Public with Their Heads Uncovered. Retrieved from http://www.independent.co.uk/news/world/middle-east/my-stealthy-freedom-women-in-iranstep-up-hijab-campaign-by-filming-themselves-walking-in-public-with-their-heads-uncovered10149226.html

Scott, J. (1987). Weapons of the Weak: Everyday Forms of Peasant Resistance. Yale University Press.

Sharp, L. A. (2000). The Commodification of the Body and its Parts. Annual Review of Anthropology, 29, 287-328. http://doi.org/10.1146/annurev.anthro.29.1.287

Shirazi, F., \& Mishra, S. (2010). Young Muslim Women on the Face Veil (Niqab): A Tool of Resistance in Europe but Rejected in the United States. International Journal of Cultural Studies, 13(1), 43-62. http://doi.org/10.1177/1367877909348538

Sutton, B. (2007). Naked Protest: Memories of Bodies and Resistance at the World Social Forum. Journal of International Women's Studies, 8(3), 139-148.

Tabnak.ir. (2013, December 8). Rohani's Government Views on Facebook, Morality Police, and the Hijab Issue. Retrieved from http://www.tabnak.ir/fa/news/363095/نحاه_دولت_روحانى-به-فيس-بوك كثت

Terman, R. (2010). The Piety of Public Participation: The Revolutionary Muslim Woman in the Islamic Republic of Iran. Totalitarian Movements and Political Religions, 11(3-4), 289-310. http://doi.org/10.1080/14690764.2010.546086

Threadgould, J. (2015). My Stealthy Freedom: How Women Take to Social Media in Their Protest Against Compulsory Hijab in Iran. Retrieved from http://www.huffingtonpost.com/jakethreadgould/my-stealthy-freedom-how-women-take-to-social-media_b_7203948.html

Tilly, C. (1991). Domination, Resistance, Compliance ... Discourse. Sociological Forum, 6(3), 593602.

Treacher, A. (2003). Reading the Other Women, Feminism, and Islam. Studies in Gender and Sexuality, 4(1), 59-71. http://doi.org/10.1080/15240650409349215

Van Eemeren, F. H. (Ed.). (2002). Advances in Pragma-Dialectics. Vale Press. 


\title{
FACEBOOK AS A TOOL FOR DISCURSIVE RESISTANCE: A CASE STUDY
}

Van Eemeren, F. H., \& Grootendorst, R. (1992). Argumentation, Communication, and Fallacies.

New Jersey: Lawrence Erlbaum Associates, Inc.

Van Eemeren, F. H., \& Grootendorst, R. (2004). A Systemic Theory of Argumentation: The Pragma-

Dialectical Approach. New York: Cambridge University Press.

Wassef, N. (2001). On Selective Consumerism: Egyptian Women and Ethnographic Representations.

Feminist Review, 69(1), 111-123. http://doi.org/10.1080/014177800110070148

Wodak, R., \& Meyer, M. (Eds.). (2009). Methods of Critical Discourse Analysis (2nd ed.). London:

Sage.

Zizek, S. (2009). What It Means to Be a Revolutionary Today. Marxism 2009. London.

\section{Contact Details of Authors:}

\section{Ehsan Dehghan}

Department of English,

Faculty of Modern Languages and Communications

Universiti Putra Malaysia

43400, Selangor, Malaysia.

Email: ehsan.phil@gmail.com

\author{
Afida Mohamad Ali \\ Department of English, \\ Faculty of Modern Languages and Communications \\ Universiti Putra Malaysia \\ 43400, Selangor, Malaysia \\ Email:afida@upm.edu.my
}

\section{Biodata}

Ehsan Dehghan is an MA student in the Department of English, Faculty of Modern Languages and Communications. He will be moving on to pursue his $\mathrm{PhD}$ in Australia. His research interests revolve around Discourse Studies, social problems, New Media, and Critical Theory. Specifically, he is interested in theorization of online activism, and the methodological, theoretical, and analytical issues involved in this regard.

Afida Mohamad Ali (PhD) is a senior lecturer in the English Language Department, Faculty of Modern Languages and Communication, Universiti Putra Malaysia. Her research interests are mainly in the areas of LSP/ESP, corpus linguistics, and genre analysis, specifically, genres used in business, finance, health, tourism and the new media. 